\title{
Transformation of Local Wisdom Value about Kerawang Gayo
}

\author{
Rita Fitri \\ \{ritafitri1994@gmail.com\} \\ Postgraduate Social Anthropology, Universitas Negeri Medan, Indonesia
}

\begin{abstract}
This study aims to determine how is the transformation of the local wisdom value about Kerawang Gayo in the District of Kebayakan, Central Aceh District. This research was conducted through qualitative research with a descriptive approach. The research informants were determined by a purposive sampling technique involving traditional leaders, Kerawang Gayo's craftsmen, and the tourism department. The data collection techniques were done through interviews, observation and documentation study. The results showed that changes in socio-cultural conditions that affect the transmission of culture that exists in society. Because by understanding changes in at least two conditions or circumstances that can be known namely the state of pre-change and post-change. Pre changes to the filigree motif gayo poured into itupitu space (sevenroom house), and after the change poured into ulen-ulen (moon cloth), souvenirs or souvenirs that are only found in the Gayo's tribe. Therefore, a transformation is carried out to preserve local culture so that it can survive and be enjoyed by the next generation without changing the original structure and meaning contained there.
\end{abstract}

Keywords: Transformation, Local Wisdom, Kerawang Gayo's Craftsmen

\section{Introduction}

Culture has values that are always inherited, interpreted, and implemented along with the process of social change that occurs. Culture is a system of meaning, where the patterns of meanings or meanings are intertwined as a whole in symbols transmitted historically, a system of conceptions inherited in symbolic forms by which humans can communicate, preserve and develop all of their knowledge and attitudes towards life. Geertz said that culture is the work of humans who can develop their attitudes towards life and be passed on from one generation to the next. Geertz's concept of symbolic culture is a hermeneutic approach, with this approach humans inspire it to see culture as a text that must be read, translated and interpreted [1].

Every community certainly have knowledge based on the experiences and attitudes of a community, this concept is usually referred to as local wisdom, local wisdom, local knowledge, or local intelligence (local genius) [2]. Local wisdom is formed based on experiences that have been experienced in people's daily lives so that these experiences become knowledge that is understood and carried out together by the community because they are seen to have value and are useful and become part of people's lives. Culture is an idea that refers to the system of knowledge and beliefs that become guidelines for regulating their actions. Local wisdom is a culture because local wisdom is knowledge gained from the experiences of previous people. 
So with the existence of local wisdom in the community become a reference and guide in the daily behavior of the whole community taught from generation to generation [3]. One of the local pearls of wisdom in the Gayo tribe is the Kerawang Gayo. Kerawang Gayo is a symbol in the form of motifs or engravings which are the result of the traditional thinking of the Gayo people, which in this motif contains the mandate and advice for the people as well as communication tools used in ancient times. And for these motives is a mandate leftover for the next generation of Gayo people. This Kerawang Gayo has a value of beauty, which illustrates the personality of the Gayo community whose character determines the position of a customary Gayo caste.

At the beginning of its development, the symbols or motifs of Kerawang Gayo were poured on wood taken from the natural surroundings. The carved motif is carved and made as decoration at the local community house called umah pitu space (seven-room house). It turns out that the carving of the motif does not stop at wood carvings, the skills of the people also create new creativity where Kerawang's motifs are poured on woven art (mats and so on) knowledge is increasingly developing, making Kerawang Gayo have a high enough artistic value. Now the Kerawang motif has been poured into the ulen-ulen (moon cloth) cloth that is used when welcoming guests or when performing traditional Gayo tribal events and has been modified to the traditional wedding attire and even souvenirs to preserve local culture without losing structure and original meaning contained there.

The result of previous research conducted by Ferawati (2010) Postgraduate ISI Padang Panjang on "Kerawang Gayo Motif on Clothing Custom Bridal Central Aceh" The results showed that Kerawang Gayo motif poured in traditional clothes society wedding of Gayo people because it has aesthetic value and significance in the clothes [4]. The second study was done by Anshar Salihin2016 entitled "Kerawang Gayo carving motifs at the Gayo traditional house in Central Aceh district". The results of this research showed that he found thirteen forms of carving motifs found in the Gayo traditional house, each of which had a philosophy in the form of a fairy mistake that contained teachings or guidance relating to the life of the Gayo community.

The motifs of the Gayo filigree carvings in the Gayo traditional house include emun departing (clouded clouds), emun beriring (cloud lined) emune berkune (branching clouds) emunmupesir (scattered clouds) emunmutangkas (clouds gathering) twisted rope (multiple twisting) shoots buds (shoots) bamboo shoots) turtle dove (measurement) eye ni lo (sun) Sarak Opat (Sarak four) nege (dragon) Iken (fish) and speckled (chicken). According to the results of previous studies above, it appears that both studies about the meaning of Kerawang Gayo. It's just that the motive findings from Ansar Salihin more. This is because the creativity of the community has increasingly developed, but the original meaning and structure have not changed [5]. Based on the description above, the authors feel the need to research the transformation of local wisdom values about Kerawang Gayo?

\section{Method}

This type of research was qualitative with a descriptive approach [6]. The informants in this study were determined based on purposive sampling techniques based on their ability to provide information to answer the problem formulation in this study. There were 4 informants in this study consisting of 1 person as a traditional figure who explained the meaning and function of the Gayo filigree for the Gayo community. While 2 Kerawang Gayo craftsmen, 
who designed the filigree design in the process of embroidering the Kerawang motif of Gayo. and 1 person is from the tourism office. This research was conducted in Bukit Eweh Tami Delem, Kebayakan District, Central Aceh Regency. The data collection techniques were conducted through in-depth interviews, observation, and study of documentation. Whereas in data analysis done by reducing data, data categories, synthesis and formulate certain statements [7].

\section{Results and discussion}

Socio-cultural change conditions affect the process of cultural transmission that exists in society. The changes in cultural transmission in a society are also called cultural transformation. Gayo people do Kerawang Gayo transformations because transformation is a scientific concept or an analytical tool to understand the world. To understand the changes that exist in the Gayo community related to local wisdom about the Kerawang Gayo, then we must see two changes that occur are the state of pre-change changes and post-change conditions.

The pre-change situation in the Kerawang Gayo is seen in the tools used before the modernization world entered the Gayo tribe. The motif was poured into the Gayo traditional house decoration which was called the itu-pitu space (seven-room traditional house) and the form of woven on a mat that was done by women. At that time, they did not know the name of uluh-ulen (moon cloth) and other souvenirs that existed at this time. This is as stated by the informants "amanbengi" as follows: "... in the past we did not know the name of bracelets and other souvenirs, we only know the filigree in traditional houses and woven mats ..."

Apart from ignorance about other developments, it turns out that the Gayo community used to have difficulty in reading and writing. Therefore, there is the role of education that is carried out to be more focused on the world of education to learn even more creativity in interpreting what is the Kerawang Gayo, so it does not only rely on the same thing. As stated by informants "aman bengi" as follows:"... just because it's hard to read so the filigree's meanings and motives stay that way..."

But soon after the post-changes and the society also recognized the name of education, as well as learn how to sew, then the development of motifs was already more than the basic motif only consists of five motifs. But that does not diminish the meaning and structure in it, these five basic motifs are always applied both in traditional houses, traditional ulen-ulen bridal costume clothing, souvenirs, robe, hijab and wedding equipment at wedding events.

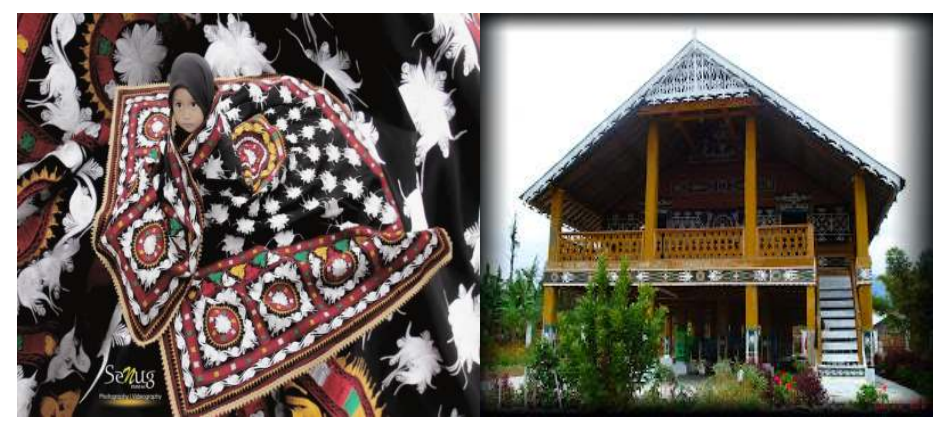

Fig. 1. Seven-room traditional house 
This research involved two people in transforming to preserve local culture. The first is a traditional figure in 2005. Customary leaders have begun producing their gayo filigree on equipment for carrying out traditional Gayo tribal ceremonies for use in weddings and circumcisions. When the wedding ceremony is used, the bride and groom must use the KerawangGayo, namely upuhuluh-ulen. This was done because the community interpreted that this upuhulen-ulen symbolize the height of the ideals in the sense that the bride and groom were able to navigate the trials of life in the household under the combination of motifs and distinctive colors. The motif consists of motives emun berangkat, pucuk rebung, puter tali, tapak seleman, and peger. Then combined with colors that are tailored to the motif, namely yellow, white, green, red and black. And this has its meanings and meanings and functions contained in its use. Not only up to here, but the community poured this Kerawang Gayo craft into several forms of souvenirs such as shal, bracelets, bridal clothing, household items, designed in such a way without losing the original meaning and structure in order to enhance local wisdom by transforming the next generation so that This Kerawang Gayo doesn't just disappear.

Then one of the craftsmen named "Ratna Ilawati" works as a civil servant. In addition to his profession as an employee teacher, he also learned to sew filigree motifs gayo which he had done since he was a girl. He was personally very interested in pursuing his field even though he felt the level of difficulty was very high but did not give up so easily. On the sidelines of his busy life, he took the time to meet the demands of consumers. The goods they produce are in the form of a robe or shirt. This is one of the transformations that he did by pouring it into many forms that were previously only centered on the Gayo traditional house, but are now more creative in using the openwork gayo motif, including in making clothes according to demand. This is one of the efforts made by the gayo community to preserve local culture so that it can survive and be enjoyed by the next generation. Although the level of difficulty in pursuing this field must be under full concentration, follow the pattern, and must be patient in doing so if you want to get optimal results. As stated by the informant "Ratna Ilawati" as follows: "... seeing it is indeed easy, but the difficulty level sometimes becomes an obstacle, it must be in full concentration if it is not, messy and not according to the pattern it will be bad..."

Transformation is a business that is done to preserve the local culture to survive and can be enjoyed by the next generation. Kerawang Gayo will survive if the communities can keep what we have as well as the policies of the government related to the policy of protection of indigenous peoples' rights and empowerment of indigenous peoples is not expected to overlap with customary law.

Traditional stuff in dealing with the global market only has two choices so that local wisdom can survive. First, because the shape is attractive and recognized by the wider community, and second, it is developing forms so that the design is more attractive and follows the market's needs. The point of the first point is that there is no guarantee of surviving in its form, there is no change and monotony. While the purpose of the second point is to stay afloat, because every time there is an automatic development of forms and to follow market tastes, but what must be maintained from these developments is not to damage the structure and meaning contained there, eliminating the philosophy or commercial products of local culture.

To support the development of the Kerawang Gayo to become a global market promotion conducted is to instill the cultural value and design skills of the Kerawang Gayo to the younger generation through the world of education. Providing skills through special training to the Gayo community in producing Kerawang Gayo products. The provision of modern tools in 
the production of Kerawang Gayo is the collaboration between craftsmen of Kerawang Gayo with academics, artists and designers who understand Kerawang Gayo. then maintaining the Kerawang Gayo promotion locally and nationally. If this can be realized, then the openwork of Gayo will not only be the identity of the community, it can also increase the economy of the Gayo people.

\section{Conclusion}

In preserving the values of local cultural wisdom, it is necessary to collaborate between the craftsmen of Kerawang Gayo with academics, designers and artists who understand the Kerawang Gayo. and instilling cultural values in us. To maintain the identity of the Gayo tribe without changing the original structure and meaning within it.

\section{References}

[1] Geertz, Clifford. 1992a. Tafsir Kebudayaan.Kanisius Press: Yogyakarta

[2] EkaPermana, Cecep. 2010. KearifanLokal Masyarakat Baduydalam Mitigasi Bencana. Jakarta: WedatamaWidya Sastra

[3] Keesing. 2005. Teori-TeoritentangBudaya, JurnalAntropologi. No.52-3313-6243-1

[4] Ferawati. 2013. Motif kerawanggayo pada busanaadatpengantin di acehtengah. ISI Padang panjang: jurnalekspresiseni vol 15. No $1: 1-147$

[5] Salihin, Anshar 2019. Motif UkiranKerawangGayo Pada RumahAdatGayo Di Kabupaten Aceh Tengah. program pascasarjana ISI padangpanjang : Gorga Jurnalsenirupa Vol.8 No.1

[6] Moleng, Lexy. (2005). MetodologiPenelitianKualitatif. Bandung : PT. RemajaRosdakarya.

[7] Bungin, Burhan. (2003). Analisis Data PenelitianKualitatifPemahamanFilosofis dan MetodologiskeArahPenguasaan Model Aplikasi.Jakarta : PT. Raja GrafindoPersada. 